form $>$ water-soluble $>$ Fe-Mn form $>$ organic bounded $>$ carbonate form $>$ exchangeable form. (d) Fe-Mn plays a crucial role in releasing $\mathrm{F}^{-}$in groundwater. (e) Intercalated zeolitic clay in sediment samples could be the main source of $\mathrm{F}$ and $\mathrm{B}$.

Finally, collaborative approaches between government, local NGOs and local people will play a vital role towards successfully implementing water management strategies in the DRB. As majority of the water sources in the study area are affected with $\mathrm{F}^{-}$concentration, an alternative source of water, such as pipeline from uncontaminated surface water resources, rainwater harvesting, watershed management, artificial groundwater recharge, etc. should be considered.

1. Deshmukh, A. N., Shah, K. C. and Sriram, A., Coal ash: a source of fluoride pollution, a case study of Koradi Thermal Power Station, District Nagpur, Maharashtra. Gondwana Geol. Mag., 1995, 9, 21-29.

2. Rao, S., Fluoride in groundwater, Varaha River Basin, Visakhapatnam District, Andhra Pradesh, India. Environ. Monit. Assess., 2009, 152, 47-60.

3. Karro, E., Indermitte, E., Saava, A., Haamer, K. and Marandi, A., Fluoride occurrence in publicly supplied drinking water in Estonia. Environ. Geol., 2006, 50, 389-396.

4. Smedley, P. L. and Kinniburgh, D. G., A review of the source, behaviour and distribution of arsenic in natural waters. Appl. Geochem., 2002, 17(5), 517-568; https://doi.org/10.1016/S08832927(02)00018-5.

5. PHED, Public Health Engineering Department, Government of West Bengal - activities and achievements in rural drinking water supply and other areas. 2007; http://www.wbphed.gov.in/ applications/im/uploads/000643.pdf (accessed on 12 August 2018).

6. Thapa, R., Gupta, S. and Reddy, D. V., Application of geospatial modeling technique in delineation of fluoride contamination zones within Dwarka Basin, Birbhum, India. Geosci. Front., 2017, 8(5), 1105-1114; https://doi.org/10.1016/j.gsf.2016.11.006.

7. Edmunds, W. M. and Smedley, P. L., Fluoride in natural waters. In Essentials of Medical Geology (ed. Selinus, O.), Elsevier Academic Press, London, 2005, pp. 301-329.

8. Thapa, R., Gupta, S. and Kaur, H., Delineation of potential fluoride contamination zones in Birbhum, West Bengal, India, using remote sensing and GIS techniques. Arab. J. Geosci., 2017, 10(527), 1-18; https://doi.org/10.1007/s1251 7-017-3328-y.

9. Woods, W. G., An introduction to boron: history, sources, uses, and chemistry. Environ. Health Perspect., 1994, 102, 5-11.

10. Sen, K. K., Datta, R. K. and Bandopadhaya, S. K., Birbhum coalfield - a major coalfield discovered. Proceedings in National Level Seminar on Coal Resources of India, 1987, pp. 417-427.

11. Sen, K. K. and Vijaya, Palynological study of the Dubrajpur Formation in the Mesozoic Succession, Pachami area, Birbhum coalfield, West Bengal. J. Palaeontol. Soc. Ind., 2005, 50(1), 121-133; http://palaeontologicalsociety.in/vol50_1/v8.pdf

12. Deng, Y., Nordstrom, D. K. and McCleskey, R. B., Fluoride geochemistry of thermal waters in Yellowstone National Park: I. Aqueous fluoride speciation. Geochim. Cosmochim. Acta, 2011, 75(2011), 4476-4489; https://doi.org/10.1016/j.gca.2011.05.028.

13. Thapa, R., Gupta, S., Gupta, A., Reddy, D. V. and Kaur, H., Geochemical and geostatistical appraisal of fluoride contamination: An insight into the Quaternary aquifer. Sci. Total Environ., 2018, 640-641, 406-418; https://doi.org/10.1016/j.scitotenv.2018.05. $\underline{360}$.
14. Uppin, M. and Karro, E., Geological sources of boron and fluoride anomalies in Silurian-Ordovician aquifer system, Estonia. Environ. Earth Sci., 2012, 65, 1147-1156, doi: 10.1007/s12665-011-1363-7.

15. Desbarats, A. J., On elevated fluoride and boron concentrations in groundwaters associated with the Lake Saint-Martin impact structure, Manitoba. Appl. Geochem., 2009, 24(2009), 915-92.7; doi:10.1016/j.apgeochem.2009.02.016.

16. Pennisi, M., Bianchini, G., Muti, A., Kloppmann, W. and Gonfiantini, R., Behaviour of boron and strontium isotopes in groundwater-aquifer interactions in Cornia Plain (Tuscany, Italy). Appl. Geochem., 2006, 21, 1169-1183.

17. Rafique, T., Naseem, S., Bhanger, M. I. and Usmani, T. H., Fluoride ion contamination in the groundwater of Mithi sub-district, the Thar Desert, Pakistan. Environ. Geol., 2008, 56(2), 317-326; doi:10.1007/s00254-007-1167-y.

18. Appelo, C. A. J. and Postma, D., Geochemistry, Groundwater and Pollution, CRC Press, New York, 2005, 2nd edn.

ACKNOWLEDGEMENTS. We are grateful to SERB, India for financial assistance to the project (project no. SB/ES-687/2013 dated 24.03.2015) and also acknowledge DST, Government of India for providing financial support to set-up a sophisticated laboratory in the Department of Environmental Science under FIST programme. We would also like to thank Central Ground Water Board, Survey of India and Geological Survey of India for their help and support.

Received 11 September 2019; revised accepted 8 January 2020

doi: $10.18520 / \mathrm{cs} / \mathrm{v} 118 / \mathrm{i} / 1292-1296$

\section{Financialization and its impact on the nature of knowledge production in bioeconomy}

\section{P. Omkar Nadh*}

Institute for Social and Economic Change, Bengaluru 560 072, India

The growth of medical biotechnology (MBT) globally over the last few decades has brought to light several significant changes in various aspects of society. The most prominent impacts were witnessed in the organization of industrial activity, and the nature of knowledge production. With innovation occupying the centre stage in the creatively destructive economies, financial actors and institutions became important in fuelling innovations. Such dominance of financialization has in turn led to the constitution of several new relationships among various actors and the emergence of a new business culture. This constitution of the 'new' is also a result of the active involvement of the state through a favourable policy environment. In all

*e-mail: omkar@isec.a.cin 
of these happenings, a question that is widely debated is, 'how is the nature of knowledge production impacted due to the emergence of a new business culture in the current innovation-led economies?' This communication delineates the emergence of this new business culture and its relationships, specifically in the context of MBT, and how those changes have impacted the nature of knowledge production.

Keywords: Bioeconomy, financialization, knowledge production, medical biotechnology, patents.

DESCRIBING the changes in the nature of global economy and capitalism in general, Fumagalli and Lucarelli ${ }^{1}$ point to the rising of a dominant phenomenon, i.e. 'the role played by knowledge in the accumulation process and the centrality of financial markets as a source of financing the innovative activity (especially, those based on knowledge)'. On the other hand, it has been witnessed how after the completion of genome sequencing by the Human Genome Project (HGP), there was a drastic and widespread increase of business models based on advancements in life sciences. While epistemological advancements in life sciences certainly played a crucial role in such drastic emergences, this situation is also a result of active participation by various financial actors like venture capitalists (VCs) and private equity fund investments in knowledgebased businesses that had no tangible products. It was a high-risk enterprise given the fact that the biological innovations are complex in nature and require a higher gestation period compared to innovations in other areas. Given this nature of high risk, a culture of business has emerged where intangibles like patents became assets that derive monopoly rents ${ }^{2}$. The impetus to such emergence of patents as an asset that can derive rents was provided by the legislative changes that took place in the United States, later followed by other developed and developing (In developing countries like India, there was direct pressure from multilateral organizations like the World Trade Organization (WTO) to introduce product patents.) countries. The harmonization of patent laws across the globe imposed through multilateral organizations like WTO, paved the way for a more or less similar business models across the globe.

While the assetization of patents had the potential for monopoly rents over a stipulated period of time, it also brought along a potential crisis in the form of huge decline in revenues once the patent expires. For example, during the last few decades, the global pharmaceutical industry was struggling with a phenomenon called innovation cliff', wherein it would lose existing patents and not have enough patentable material in its pipeline ${ }^{3}$. This situation necessitated the pharmaceutical industry, based on risk assessment, to concede a little market space to new actors with innovative potential known as dedicated biotech firms (DBFs). It was believed that the completion of a HGP would provide a means to deliver a number of blockbuster biologicals and in order to do so there is a need for these new actors. With the emergence of DBFs, a structural relationship was witnessed in the previous pharmaceutical industry market space. DBFs were managing the upstream terrain of research and development (R\&D), and the pharmaceutical companies in the downstream were taking forward the outcomes of this $R \& D$ towards drug manufacturing. But in the emergence of such relationship, an important institution that played an active role was universities and academic spaces exemplified by the fact that a large number of DBFs were spinoffs from universities and mostly by university faculty ${ }^{4}$. The Bayh-Dole Act in the US transformed universities into commercial entities with new goals and missions. It is often argued that in this perusal of new mission, a new academic culture was taking shape where universities were being more and more integrated into the market structure and affecting the nature of knowledge production itself in order to ensure that the market logic works. Universities started acting more and more entrepreneurial and so did scientists. This communication is an exploration of all of these issues in relation to one another to comprehend the extent of the impact of such relationships on the nature of knowledge production.

During the early 20th century it was only big businesses that were engaging in the in-house R\&D. However, by the end of the century, the relationship between science and industry started transforming, mostly with biotech start-ups that were engaging in science-based business (According to Pisano ${ }^{4}$, 'science based business' means, it just does not attempt to use the existing scientific knowledge but also advances scientific knowledge and captures (economic) value of such advancement.) ${ }^{5}$. Around same time, large in-house R\&D laboratories of big industries were either shutting down or becoming too narrow in their focus because of their increasing short-term interest on 'maximization of shareholder value' ${ }^{5}$. This engagement in basic sciences research as an entrepreneurial activity is qualitatively different from the previous engagement with the applied research that guaranteed outputs and thereby returns on investment. The spread of this new entrepreneurial culture started with Genetech, the first DBF which was set up by a university-based biochemist, Herbert Boyer and an aspiring VC, Robert Swanson. The story of Genetech is important in the history of commercialization of biotechnology for a variety of reasons. It provides a comprehensive picture of the emergent business culture and the relationships between various stakeholders, and its journey became a blueprint for DBFs that followed. The most prominent stakeholders in the innovation network of MBT include financial institutions, DBFs, academia, the big pharmaceutical industry and the state. The relationship between all these stakeholders can be deciphered observing the trajectory of Genetech. 
Genetech had no tangible products when it approached for venture capital, a phenomenon very different from the existing business climate then. Swanson an aspiring VC along with his other VC partners invested in this company as an act of speculation. To quote a Genetech VC investor's response about the level of risk they took upon themselves:

'Very high. I figured better than 50-50 we'd lose it. But it's rare when the odds on a new technology are better than 50 per cent. Second thoughts? Not at all. If it worked, the rewards would be obvious ${ }^{6}$.'

The company passed through different phases during its trajectory till its final stage of being rescued by HoffmanLa Roche by buying it out. For instance, Huges ${ }^{6}$ notes that, following the VC investment another major event in the company's journey was its debut in Wall Street through its initial public offering (IPO) in 1980. This IPO was idiosyncratic from conventional business practices for a variety of reasons. The company did not have a single product on market, but its stock was priced between US\$ 25 and 30 per share, a high price then despite Genentech's lack of products and sales. The firm in the first six months of 1980 had earned US\$ 81,000 on revenues of US\$3.5 million, a disheartening price-toearnings ratio. In response to a journalist, Fred Middleton a member from the Genetech management team responded: 'I think it's fair to say that the value of our company is based on its future potential. Promise and possibility, rather than products and earnings, fuelled the speculative momentum building over the Genetech offering? ${ }^{6}$.' This speculative momentum is due to valuation processes based on intangible assets like patents, and marked the beginning of a new euphoric business culture ${ }^{2}$. The company raised huge investments after its IPO.

'A minute after the opening bell, the share price skyrocketed from $\$ 35$ to $\$ 80$ - the fastest first-day gain in Wall Street history. The price peaked at $\$ 89$ within twenty minutes, rose and fell over the course of the day, and ended at $\$ 71$ at market close. Genentech had raised over $\$ 36$ million. Based on the closing price, the company's value was an estimated $\$ 532$ million. It was, (...), "the hottest stock offering in history to that time". Even the Wall Street Journal called it "one of the most spectacular debuts in memory",

Such a boom of Genetech had to come to an end. The company went into crisis in the 1990s when one of its products failed to meet market expectation. Consequently, the company was rescued by Hoffman-La Roche with a $60 \%$ buyout initially and a complete buyout in 2009 , when the crisis got escalated due to various reasons ${ }^{6}$. The Genetech story is important because it provided a blueprint for the emergent DBFs, which are now thousands in number. While such risky investments by the VCs and IPO in case of Genetech were a case of exception then, currently it has become the norm. Across the globe the increasing entwinement of financial actors and institutions in the innovation network of MBT indicates that speculative business culture is the order of the day. What is also interesting is that, despite the global financial crisis of 2008 that led to a decline in the market capitalization, the industry achieved profitability first time ever in 2009. Ironically, in the next five years, the market capitalization soared to a value of 1 trillion US dollars even without proportionately producing more services, products or higher revenues ${ }^{2}$. This explains how volatile the valuation process is and how it does not necessarily depend on development of products or services. But the question that arises here is: what is the basis for such staggeringly high valuation in such a short period of time? The answer to this question is the normalization of speculative momentum as witnessed in the case of Genetech enabled by the assetization of the intangibles like patents. Characterizing this speculative momentum that started with Genetech and has been normalized today, Mirowski ${ }^{7}$ draws an analogy of the economic process of DBFs to something like a Ponzi scheme, where more liabilities are incurred than cash flows with the trick being to lure the investments raised and cashing out before the collapse.

Table 1 provides an overview of the amount of venture capital invested across the globe and IPOs raised over the years $^{8,9}$. They also provide a picture of how venture capital (VC) and IPO are currently normalized across the globe in terms of the number of deals and amount raised.

At the outset it is important to explain the contours of the process of drug development before elucidating the relationship between biotechnology and big pharma. Typically, the drug development process involves two major

Table 1. Global VC and IPO details over time in the US

\begin{tabular}{lccccc}
\hline & \multicolumn{2}{c}{ IPO } & & \multicolumn{2}{c}{ VC } \\
\cline { 2 - 3 } \cline { 5 - 6 } Year & $\begin{array}{c}\text { No. of } \\
\text { deals }\end{array}$ & $\begin{array}{c}\text { Amount } \\
\text { raised (avg) } \\
\text { (million dollars) }\end{array}$ & & $\begin{array}{c}\text { No. of } \\
\text { deals }\end{array}$ & $\begin{array}{c}\text { Amount } \\
\text { raised (avg) } \\
\text { (million dollars) }\end{array}$ \\
\hline 2005 & 45 & 41 & NA & NA \\
2006 & 49 & 41 & & 336 & 5589 \\
2007 & 51 & 58 & & 386 & 5547 \\
2008 & 6 & 22 & & 358 & 4623 \\
2009 & 10 & 92.8 & & 315 & 3771 \\
2010 & 19 & 51 & & 324 & 3557 \\
2011 & 13 & 81.4 & & 292 & 3824 \\
2012 & 17 & 53.6 & & 281 & 3925 \\
2013 & 43 & 72.5 & 322 & 4539 \\
2014 & 90 & 72.3 & 341 & 5879 \\
2015 & 65 & 81.5 & 387 & 10126 \\
2016 & 49 & 58 & 344 & 8483 \\
2017 & 55 & 98.4 & 333 & 8768 \\
\hline
\end{tabular}

Source: refs 8 and 9 . 
steps. One is the discovery of a lead molecule which can either be a biological molecule or a chemical molecule, and the next big step is to take that molecule over a threephased clinical trial. Identifying lead molecules involves robust $R \& D$ and of late, the multinational pharmaceutical companies are facing a serious crisis in the form of patent cliff and are in dire need of innovation. The revenues generated by blockbuster (A blockbuster drug is something that generates revenues in the order billion US dollars.) drugs would start declining once they go 'offpatent' and cease to be monopoly entities on being prone to generic manufacturing. Secondly, since most major pharmaceutical companies are publicly traded, the industry is expected to grow at 13 earnings per share (EPS), while the industry could only manage 8-10 EPS. Also between 2002 and 2012, the annualized return on equity for the industry was $-1.2 \%$, according to the New York Stock Exchange Arca Pharmaceutical Index ${ }^{3}$. To fulfil the expectations of the stock market as mentioned above, at least 3-5 new chemical entities need to come to the market. On the other hand, existing studies show that only one in every five drugs that enter clinical trials is success$\mathrm{ful}^{3}$. Such a crisis and pressure from the financial markets necessitate the industry to have robust $R \& D$ mechanisms, and it is such situation of crisis that provides market space for the emergence of DBFs. For Mirowski ${ }^{10}$, corporations were getting rid of their in-house $R \& D$ because they started treating it as a fungible commodity whose cost is cheaper outsourcing than doing it by themselves. He argues that in one important sense 'the reengineering of corporation implied the commodification of science'. On the other hand, though the MBT firms also have intentions to manufacture drugs by themselves, the costs involved in bringing a new drug to the market restricts them from such endeavours. The Tufts Centre for Study of Drug Development, Massachusetts, estimates the current cost of drug development at 1395 million US dollars and capitalizing out-of-pocket costs to the point of market approval at a real discount rate of $10.5 \%$ is estimated as 2258 million US dollars ${ }^{11}$. Table 1 provides a picture of how drug development costs have escalated over time.

In such a scenario, a new relationship between big pharmaceutical companies and DBFs emerged. While the latter was in dire need of innovation, the former lacked the capacity to bring a new drug to the market; however, both these entities are determined to a certain extent by the financial institutions and markets. While VCs led to emergence of DBFs, the publicly traded big pharmaceutical companies are strained by the expectations of their shareholders.

In such a mutually benefitting exercise, the relationships usually found are either outsourcing molecules from upstream companies by downstream companies, or mergers and acquisitions (M\&A). The source behind the emergence of such relationships has to be again attributed to a large extent to the property rights in the form of patents. Patenting that grants ownership has allowed the DBFs to outsource their molecules and charge royalties. While patenting as such is a commonly agreed norm in the capitalist dynamics, ironically, instances of preventing patents in the form of gift by the big pharmaceutical companies has also been witnessed. In 1998, the National Institutes of Health (NIH), USA, wanted to establish a single nucleotide polymorphism (SNP) consortium and allocated 30 million US dollars to prevent the SNP data from being patented by biotech companies and to keep it in public domain. In 1999, the initiative became much bigger to 45 million US dollars with contributions from Wellcome Trust and ten major multinational pharmaceutical companies ${ }^{10}$. While such acts at the outset might seem to be altruistic and philanthropic, a much more nuanced analysis would provide the basis behind such altruistic actions. The altruism is because, the pharmaceutical companies were dictated by a market logic which is beneficial to them. It was becoming expensive for the pharmaceutical firms to out-license patents from the biotech firms and it is in their interest to have that information in the public domain. This indicates how dynamic and non-singular the market logics (The pharmaceutical companies were keen on patenting the drugs.) are $^{12}$.

Universities have become an important source of innovation because of the need and essence of cutting-edge research and innovation for economic activity. The beginnings of such relationships can be traced back to the period between the World War-I and the World War-II, such as those between Eli Lilly and University of Toronto, Canada, and Eli Lilly and University of Rochester, USA in 1922 and 1931 respectively ${ }^{13}$. However, such relationships went on a decline once the large companies started their own in-house R\&D and universities were supported by federal funding. A revolution in biotechnology rejuvenated the industry's interest to establish relationship with the universities. At the beginning of the so called biotech revolution around one-third of university research was supported by the industry ${ }^{14}$. Stanford University, USA has become an exemplar of an entrepreneurial university, especially in the field of life sciences through licensing of a patent on rDNA technology

Table 2. Estimates of drug development costs over the years

\begin{tabular}{lcc}
\hline Study & $\begin{array}{c}\text { Clinical success rate } \\
(\%)\end{array}$ & $\begin{array}{c}\text { Cost estimate } \\
\text { (US \$) }\end{array}$ \\
\hline DiMasi et al. (2003) & 21.5 & 802 million \\
Adams and Brantner (2006) & 24.0 & 868 million \\
Adams and Brantner (2010) & 24.0 & 1.2 billion \\
DiMasi and Grabowski (2007) & 30.2 & 1.2 billion \\
Gilbert et al. $(2003)$ & 8 & 1.7 billion \\
O'Hagan and Farkas (2009) & NA & 2.2 billion \\
Paul et al. (2010) & 11.7 & 1.8 billion \\
Mestre-Ferrandiz et al. (2012) & 10.7 & 1.5 billion \\
\hline
\end{tabular}

Source: ref. 11. 
developed by Stanley Cohen and Herbert Boyer ${ }^{15}$. Though universities were involved in sponsored projects before, with Stanford what one has witnessed is an institutionalization of commercial research. Technology Transfer Offices (TTOs) were becoming an integral part of universities, DBFs also emerged from the universities to commercialize their research. These relationships are usually of several types, such as universities understanding sponsored projects, universities licensing their patents and collaborative research by university and industry, consultation by members of faculty to industry, equity holding in companies by universities or faculty, support of graduate students by companies, etc.

'In numerous instances, the boundary between a university and a biotech firm is blurred. The founders of a substantial number of biotech firms include the professors (many of them world-renowned scientists) who invented the technologies that the start-ups licensed from the universities, often in return for an equity stake. These companies frequently maintain their links with the universities, working closely with faculty members and postdoctoral candidates on research projects, and sometimes using the university laboratories. In many instances, the founding scientists even retain their faculty posts ${ }^{4}$,

According to a study by Blumenthal ${ }^{13}$, between 1980 and 1983 around 140 million US dollars was poured into research conducted by 13 universities by big pharmaceutical companies in the US. From mid to late 1990 s, $90 \%$ of the firms conducting research in life sciences had some type of relationship with universities and about onequarter of life sciences faculty from universities in the US received support from the industry for their research project. Also, $50 \%$ of the life science faculty acted as consultants for the industry and $7 \%$ of them held equity in companies that were working in the areas related to the research they were pursuing at their universities. In 1999, a survey showed that $68 \%$ of universities in Canada and the US held equity in companies that sponsored research to their faculty ${ }^{13}$.

This trend has only been increasing with time. Though federal funding is still a major source for university research, empirical evidence shows an increasing trend in R\&D expenditure by the industry and the universities themselves. Between 2007 and 2017, while the state and local agencies and federal government funding for university research decreased by $10 \%$ and $13.8 \%$ respectively, universities and industry funding increased by $30.6 \%$ and $10.6 \%$ respectively ${ }^{16}$. While there was a decline in the share of federal funding, the life sciences discipline was receiving more than 50\% (Between 2007 and 2017, the National Institutes of Health life sciences research funding hovered between $43.9 \%$ and $39.1 \%$, and funding for other life sciences research between $10.5 \%$ and $9.8 \%$ of the total federal funds ${ }^{16}$.) of the total federal funding. The above statistics indicates an increase in the knowledge commercialization by universities, since an increase in university expenditure is implicitly linked with the resources it generates by strategies such as licensing and other options. Specifically, with regard to life sciences research, the data available with the American Association for the Advancement Science depict a similar trend.

In 1994, data from Association of University Technology Managers (AUTM) showed that 120 US universities spawned 175 spin-offs which had further increased across disciplines with 155 universities producing 655 spin-outs in 2012, with more than half of them focusing on life sciences ${ }^{17}$. Recent data show that while the top schools recorded 93 life sciences start-ups, the number almost doubled to 182 in 2015 (ref. 18). Life sciences and biotechnology are particularly outdoing other segments in these new proactive measures by the universities. Tables 2 and 3 provide an overview of the revenue by technology transfers and spin-offs that universities have generated over five years (2011-2015) and how life sciences has been dominating the whole scenario. Available data also suggest that the industry was able to bring at least 153 new drugs and vaccines to the market in the US through its collaborations with the universities ${ }^{19}$.

Whether it is about a VC supporting the emergence of an industry, or universities aggressively commercializing their research or patents acting as assets, all of them manifested due to broad political and legal changes that took place in the US in the late 1970s and early 1980s. This section provides an overview of such broader structural changes that took place. The birth of the biotech business model coincided with the relaxation of liabilities associated with VCs in the late 1970s, when the Department of Labour in the US legalized investment of pension funds in the venture funds that was considered illegal ear$\operatorname{lier}^{20}$. Also, the special provisions on capital gains tax which ended in 1969 were renewed in 1978 (ref. 20). Copper $^{21}$ through her study informs how from US President Ronald Regan's era, broad political changes took place in general to support the supply side of the economy and specifically how it came to affect life sciences. She in fact argues: 'The biotech revolution, (...), is the result of a whole series of legislative and regulatory measures designed to relocate economic production at the genetic, microbial, and cellular level, so that life becomes, literally, annexed within capitalist processes of accumulation $^{21}$.

The most remarkable and specific regulations that led to the commercialization of life science research and those that resulted in the spur of biomedical industry are as follows:

(1) The dramatic increase in federal funding for life sciences research in the US standing only next to the 
heavily funded defence and obligating universities to increasingly perform research for commercial interests $^{21}$

(2) In 1980, regulations in the form of StevensonWylder Technology Transfer Act, amendments to Patent and Trademark Act commonly known as the Bayh-Dole Act that allowed and in certain sense, obliged the universities to transfer technology to the industry 6 .

(3) The ruling in the Diamond versus Chakraborthy patenting case which ruled that genetically modified bacteria are patentable in and of themselves apart from their use in the process. This led to opening the window for patenting of cell lines, DNA, genes, animals and any other living organism that were 'sufficiently' modified ${ }^{22}$.

(4) The regulations that announced successive reductions in the capital gains tax encouraged VCs to invest in this industry. In 1978, the US Congress had cut the tax on investment in long-term capital gains and a year later, it also relaxed prudent fund rules that restricted the pension investments in high risk/ return endeavours ${ }^{6}$.

(5) The missing regulations of drug price control in the US also provided an advantage for the growth of this industry $^{23}$

Patents as a rewarding system to the inventors, is not new to the contemporary societies. Krimsky ${ }^{22}$ providing a brief history of patents notes that, during 1200 s a ten-year monopoly was granted to inventors of a silk-making instrument in the city of Venice, Italy. Further, Galileo was granted a patent by the Venetian State in 1594 for his invention of horse-driven water pumps. In 1624, England passed the statue of monopolies. Prior to 1790s, American colonies were granted patents by special acts of colonial legislatures. In 1790s, the US introduced in its constitution, Article 1 Section 8 which states that 'The Congress shall have the power to promote the progress of science and useful arts by securing for a limited time to authors and inventors the exclusive right to their respective writings and discoveries' (as cited in Krimsky ${ }^{22}$ ). According to $\mathrm{Krimsky}^{22}$ incremental reforms thereafter took place in patent law in the US to an extent that patenting of living organisms itself was made possible. In 1873, Louis Pasteur was provided a patent for a strain of yeast; however, the claim involved organism in a process and not the organism itself ${ }^{22}$. Krimsky ${ }^{22}$ further notes that, this changed in 1980s with the legal pronouncement in the case of Diamond (Commissioner of Patents and Trademarks) versus Chakraborthy. This case had for the first time legalized patenting of life forms. Anand Chakraborthy who was working for General Electric, US, discovered a soil microorganism, viz. Pseudomonas that can spill oil. He mixed different strains of Pseudomonas through genetic engineering (GE) for spilling oil through degradation of hydrocarbons and filed for a patent for the process of oil-spilling and the living organism itself. The claim for patenting was rejected by the United States Patent and Trade Mark Office (USPTO) on the grounds that the bacterium was both a natural and living organism. This decision was appealed at the Board of Appeals of the USPTO and the Board overturned the decision of USPTO that the bacterium (GE) was a product of nature; but it still did not grant the patent on the grounds that living organisms are in and of themselves not patentable. The case then moved to the US Supreme Court where, in a majority ruling of 5-4, patent was granted for the first time for a living organism on the grounds that a living, human-modified bacterium is a patentable subject matter under Section 101 of the patent law as a manufacture or composition of matter ${ }^{22}$. This case become a crucial force behind the proliferation of biotechnology industry in the US. To quote an industrial representative on the extent of impact the ruling has had: 'In 1980, the Supreme Court also held, in Diamond vs Chakrabarty - some believe this was a landmark decision that allowed for the progress of the biotech industry - that genetically engineered bacteria useful for cleaning up oil spills were patentable (...). Interestingly, before 1980, which is when the Supreme Court decision came out, there were only a handful of biotech companies. The innovator at the time was Genentech; then, after that, Cetus Chiron. But after Diamond vs Chakrabarty, the biotech industry grew phenomenally ${ }^{24}$.'

Along with these many other incentives such as the 1981 Economic Recovery Tax Act, which awarded tax credits for R\&D, the 1984 Patent Term Restoration Act, and 1987 Presidential Executive Order for pushing more technology transfer from federally funded universities all of them played a key role in the ascent and progress of this industry ${ }^{25}$. With the harmonization of patent laws across the globe, a similar trend can be observed even in developing countries like India.

The question in the literature with regard to knowledge production is, whether the pursuit of production of scientific knowledge should be as an end in itself or as a means to pre-determined ends? Robert Merton described the normative structure of science as possessing communism, universality, disinterestedness and organized scepticism as its essential characters ${ }^{26}$. Taking cue from the Mertonian norms, the contemporary production of scientific knowledge is hugely criticized for its violation of the normative structure. The life sciences knowledge production, especially after Genetech, is said to be increasingly commercialized defying the principle of disinterestedness and autonomy that was propounded by Merton. While there is burgeoning literature which argues that with commercialization of science, what is seen is decline in 'science for its own sake', which is knowledge production as an end in itself, Bernal ${ }^{27}$ in his monumental work on Science in History shows how such an ideal science never completely existed. In fact, he suggested that 


\section{RESEARCH COMMUNICATIONS}

Table 3. Revenue generated and spin-offs from top schools in the US between 2011 and 2015

\begin{tabular}{lccc}
\hline University & Licenses and/or options executed & Gross licensing revenue (US\$) & Start-ups \\
\hline University of Washington & 284 & $31,417,773$ & 12 \\
University of California System & 248 & $169,724,803$ & 66 \\
University of Texas System & 128 & $48,083,097$ & 23 \\
Stanford University & 88 & $88,573,239$ & 18 \\
Columbia University & 70 & $181,400,000$ & 19 \\
Massachusetts Institute of Technology & 68 & $17,000,000$ & 10 \\
New York University & 53 & $209,000,000$ & 12 \\
University of Utah & 49 & $59,495,096$ & $31,814,000$ \\
University of Massachusetts & 24 & $61,565,351$ & 4 \\
Northwestern University & 22 & $136,541,760$ & 7 \\
Princeton University & 4 & & 0 \\
\hline
\end{tabular}

Source: ref. 18 .

Table 4. Comparison of gross revenue, licenses executed and start-ups formed by top universities in the US between 2011 and 2015

\begin{tabular}{|c|c|c|c|c|c|}
\hline \multicolumn{2}{|c|}{ Licenses/options executed } & \multicolumn{2}{|c|}{ Gross revenue (US \$) } & \multicolumn{2}{|c|}{ Start-ups formed } \\
\hline Overall & Life sciences & Overall & Life sciences & Overall & Life Sciences \\
\hline 1471 & $1,038(70.56 \%)$ & $1,106,458,949$ & $1,034,615,079(93.5 \%)$ & 262 & $182(69.46 \%)$ \\
\hline
\end{tabular}

Source: ref. 18 .

science has to be directed more towards social needs ${ }^{25}$. He also cautioned that the real derogation of science is when it is valued more based on commercial ends, economic interests, private profits and means of destruction. Lewontin $^{28}$ in his famous book Biology as an Ideology hints at what is wrong in an understanding of science just as, 'an institution, a set of methods, a set of people, a great body of knowledge that we call scientific, is somehow apart from the forces that rule our everyday lives and that govern the structure of our society'.

Coming to the case of contemporary life sciences, scholars like Eztkowitz ${ }^{29}$ argue that the commercialization of knowledge and rise of entrepreneurial university is the second academic revolution, and only the next logical step in continuation of development of a medieval institution. Kleinman and Vallas ${ }^{30}$ while agreeing to the fact of increased commercialization of knowledge production in life sciences, also describe how historically scientific knowledge production was never completely autonomous and was always influenced by external factors. Slaughter and Rhoades ${ }^{31}$ argue through their theory of academic capitalism on how new circuits of knowledge are created and integrated into the new economy through active involvement of the state. While there are such different strands in the literature about the nature of scientific knowledge production, the fact is that the ongoing state of affairs, especially in life sciences and biotechnology, mirrors not just an increasing but an 'institutionalized' commercialization. The following anecdote will provide an overview of the consequences due to commercialization of scientific knowledge. After the success of Genetech, 'it was not only the business and financial worlds that showed interest in genetic engineering. Leading molecular biology departments began to buzz with the applied opportunities foreseen in their research, the patents and licenses likely to result, and the chance for institutional and personal financial gain. It was simultaneously exciting and troubled time of transition in molecular biology as the new genetic techniques swept university biomedical departments, supplanting previous experimental procedure and running up against academic policy and convention. (...) As 1978 drew to a close, the audience for genetic engineering had considerably expanded and molecular biology was starting to lose its image of a purely academic discipline. It was entering an industrial phase in which the research direction and cultural norms of American biomedicine would be realigned to more utilitarian ends and proprietary considerations ${ }^{6}$.' The next question to be answered is whether such changes are novel? Commercialization of knowledge is not novel in itself; the novel aspect is the institutionalization of such commercialization and it is certainly a hallmark of the contemporary times. Such institutionalization of commercialization also normalizes along with it several cultural changes that once were not acceptable. For example, announcing scientific results without peer review through popular press was witnessed in the case of Genetech ${ }^{6}$, but even before this Thomas Alva Edison has resorted to the same, which was heavily criticized by Henry A. Rowland, the noted experimental physicist from John Hopkins University $^{32}$. During the time of Edison such phenomena were outliers or specific cases; currently such practices are normalized. It is such increasing normalization and institutionalization of commercialization of scientific re- 
search that puts at stake all the socially relevant functions of science, if they do not adhere to the market logic.

This study demonstrates how financialization has influenced knowledge production in the case of biomedical sciences. Though we do not argue that there is any linear causality between the two, it does however demonstrate how through a network of various actors such as the DBFs, pharmaceutical industry, universities and the state, financialization has influenced the nature and culture of knowledge production. The study also provides an empirical evidence of how elements in the network of biotech innovation function in relation to each other. By examining how the nature and culture of knowledge production has transformed, we conclude two aspects. One, if it was not for the role of the state, manifestation of MBT innovation ecosystem would not had been the way it currently is. Two, from the case rested above, it is clear that currently commercialization of scientific knowledge is institutionalized. While the details discussed are only about the US scenario, the present study also helps understand the Indian scenario given the fact that it is the same model that is being emulated, albeit with a little difference.

1. Fumagalli, A. and Lucarelli, S., Valorization and financialization in cognitive biocapitalism. Invest. Manage. Financ. Innov., 2011, 8(1), 88-103.

2. Birch, K., Rethinking value in the bio-economy: finance, assetization, and the management of value. Sci. Technol. Hum. Values, 2017, 42(3), 460-490

3. Rajan, K. S., Value, Politics and Knowledge in Global Biomedicine, Duke University Press, Cambridge, 2017.

4. Pisano, G. P., Can science be a business? Lessons form biotech Harvard Bus. Rev., 2006, 1-12.

5. Pisano, G. P., The evolution of science based business - innovating how we innovate. Harvard Business School Working Paper, 2010 .

6. Huges, S. S., Genetech: The Beginings of Biotech, The University of Chicago Press, London, UK, 2011

7. Mirowski, P., The modern commercialisation of science is a passel of Ponzi schemes. Soc. Epistemol., 2012, 26(3-4), 285-310.

8. Huggett, B., Bringing up baby. Nature Biotechnol., 2018, 36(5), 393-401.

9. Morrison, C., and Lähteenmäki, R.., Public biotech in 2016 - The numbers. Nature Biotechno., 2017, 35(7), 623-629.

10. Mirowski, P., Science Mart: Privatising American Science, Harvard University Press, Cambridge, Massachusetts, USA, 2011.

11. Dimasi, J. A., Grabowski, H. G. and Hansen, R. W., Innovation in pharmaceutical R\&D: New estimates of R\&D costs. J. Health Econom., 2016, 47, 20-33.

12. Rajan, K. S., Biocapital: The Constitution of Post Genomic Life, Duke University Press, Durham, North Carolina, USA, 2006.

13. Blumenthal, D., Academic-industrial relationships in the life sciences. N. Engl. J. Med., 2003, 349(25), 2452-2459.

14. Blumenthal, D., Gluck, M., Louis, S. K. and Wise, D., Industrial support of university research in biotechnology. Science, 1986 271(4735), 242-246.

15. Rajan, K. S., Introduction: the capitalisation of life and liveliness of capital. In Lively Capital: Biotechnologies, Ethics and Governance in Global Markets, Duke University Press, Durham, North Carolina, USA, 2012.
16. American Association for the Advancement Science, 2018; https:// www.aaas.org/programs/r-d-budget-and-policy/research-scienceand-engineering-discipline (accessed on 15 February 2019).

17. Huggett, B., Biotech's wellspring: the health of private biotech in 2013. Nature Biotechnol., 2014, 32(5), 428-435.

18. Huggett, B., Top US universities, institutes for life sciences in 2015. Nature Biotechnol., 2017, 35(3), 203.

19. AUTM, AUTM University Licensing Survey - 2015, Association of University Technology Managers, Washington DC, USA, 2016.

20. Roth, C. R., From Alchemy to IPO: The Business of Biotechnology, Peresus Publishing, Cambridge, UK, 2000.

21. Cooper, M., Life as Surplus: Biotechnology and Capitalism in the Neoliberal Era, University of Washington Press, Seattle, Washington, USA, 2008.

22. Krimsky, S., Science in the Private Interest: Has the Lure of Profite Corrupted Biomedical Research?, Rowman \& Littlefield Publishers, Maryland, USA 2003.

23. Lehman, V., Doing Good by Doing Well? The Political Economy of the Medical Biotechnology Industry in the United States, UMI Dissertation Publishing, New York, USA, 2010.

24. Feisee, L., Biotech in Northeast Ohio Conference - the role of the private sector in biotechnology: research and development. Health Matrix: J. Law Med., 2002, 12(2), 357-365.

25. Loeppky, R., History, technology, and the capitalist state: the comparative political economy of biotechnology and genomics. Rev. Int. Polit. Econ., 2005, 12(2), 264-286.

26. Merton, R., The normative structure of science. In The Sociology of Science: Theoretical and Empirical Investigations, University of Chicago Press, Chicago, USA, 1973.

27. Bernal, J. D., Science in History, Penguin Books, vol. 1, 1954.

28. Lewontin, R. C., Biology as Ideology, Canadian Broadcasting Corporation, 1995.

29. Etzkowitz, H., MIT and Rise of Entrepreneurial Science, Routledge, London, UK, 2002.

30. Kleinman, L. D. and Vallas, S. P., Science, capitalism and the rise of 'knowledge worker': the changing structure of knowledge production in United States. Theory Soc., 2001, 451-492.

31. Slaughter, S. and Rhoades, G., Academic Capitalism and New Economy: Markets, State and Higher Education, The John Hopkins University Press, Baltimore, Maryland, USA, 2004.

32. Hounshell, D. A., Edison and the pure science ideal. Science, 1980, 207(4431), 612-617.

Received 16 November 2017; revised accepted 27 January 2020

doi: $10.18520 / \mathrm{cs} / \mathrm{v} 118 / \mathrm{i} 8 / 1296-1303$ 